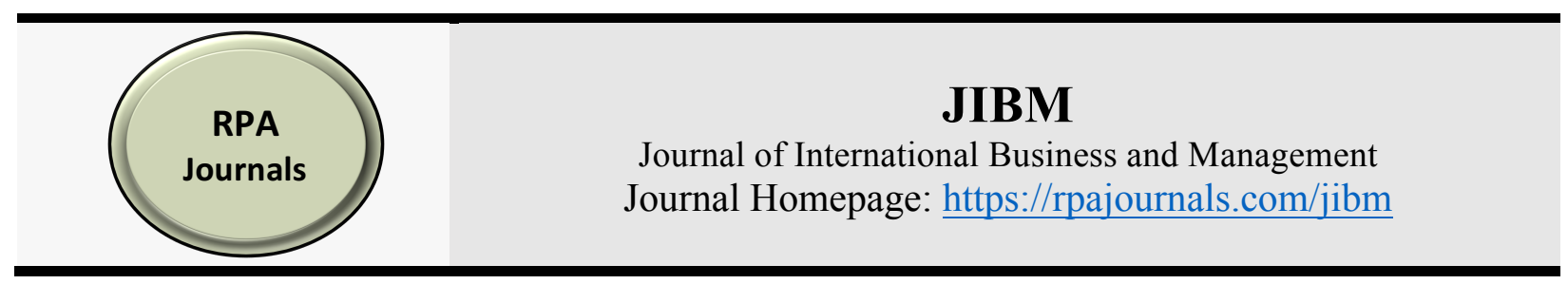

\title{
How Service Quality Affects Customer Satisfaction: A Study of Malaysian Electric Train Service (ETS)
}

\author{
Sulaiman Abdullahi Bambale ${ }^{1}$ \\ Mazuri Binti Abd. Ghani ${ }^{2}$ \\ Abdullahi Bala Ado ${ }^{* 3}$ \\ Faculty of Business Management ${ }^{1,2 \& 3}$ \\ Universiti Sultan Zainal Abidin (UNISZA), Malaysia ${ }^{1,2 \& 3}$
}

\begin{abstract}
Service quality played an important role and it affected to the customer satisfaction. Service quality has become a distinct and important aspect of the product and service Offerings. In this study, we investigated the effects of service quality on customer satisfaction in electric train service (ETS) industry Malaysia, focusing on the five dimensions in service quality which is tangible, responsiveness, assurance, reliability and empathy. Questionnaires were used to collect the data from ETS passengers at northern region Malaysia KTMB station. The hypotheses on the causal relationships among service quality and customer satisfaction were tested by using IBM SPSS Statistics version 23 statistical technique. The results show negative correlation between the customer satisfaction and five dimensions in service quality. This study helps ETS to know about their customer's satisfaction and can help them improve their service quality. Future research needs to be done to investigate in details about this study.

Keywords: Service Quality, Customer Satisfaction, Electric Train Service (ETS), Malaysia.
\end{abstract}

*Corresponding author: Abdullahi Bala Ado; Email: abdallahkmata@yahoo.com

DOI: https://rpajournals.com/jibm-2019-04-67/

\section{Introduction}

The description of excellence varies from person to person and from situation to situation. Thus, the meaning of quality of service differs among scholars and practitioners, but they usually converge in determining whether the provision of the service received meets, exceeds or fails to meet customer expectations (Lee, Kang \& Kang, 2019). Service quality plays an important role which directly affects customer satisfaction. It has become a distinct and important aspect of the product and service offering (Chen, Wang, Huang \& Shen, 2016). When delivery service to customers becomes a problem, you cannot get the customer based on the price paid for their expectation. Consumers prefer the quality of service when the price and other cost elements remain constant (Gabaix \& Laibson, 2018). The prime targets of organizations are to maximize profits and to minimize costs. Profit expansion can be achieved through service quality which rises sales when customers become satisfied. Indeed, one of the aspects that can help to increase sales is customer satisfaction, because 
satisfaction indicates customers' loyalty endorsement and repeat purchase (Hassan, Nawaz, Lashari \& Zafar, 2015).

Customer satisfaction and service quality have been proven to improve the overall performance of groups (Pan, 2015). Presently, the focus of companies is more on service quality delivery to its customers (Vogus, \& McClelland, 2016). Customer satisfaction is the central tool that helps increase sales and create revenue of companies. Consequently, customer satisfaction has become an issue of great concern to organizations and researchers alike. Therefore, this study is a contribution to the argument as to whether service quality has a direct or indirect influence on profitability in the Electric Train Service (ETS) industry in Malaysia.

ETS was firstly introduced in Malaysia In July 2015 (Loo, Chua, Foong, Loke \& Pang, 2016). It is the second electric rail service that operated in Malaysia as the first high-speed train in the country after the commuter service in Kuala Lumpur. Again, it is high-speed rail can be defined as the rail that running at and above $150 \mathrm{~km} / \mathrm{h}$. The ETS routes start from Kuala Lumpur until Padang Besar. ETS first trip departures from KL Central station exactly 09.30 am to carry about 80 passengers. This ETS replaces old train driven by diesel, launched in August 2010 to the routes of the KL-Ipoh. ETS Express service will run twice a day with a ticket price of RM80 for adults and RM40 for children to travel from Kuala Lumpur to Padang Besar, Perlis and reverse back to Kuala Lumpur.

In view of the foregoing, certain fundamental questions which this paper seeks to address includes: To what extent service quality of ETS satisfies its customers? What is the relationship between quality service delivery and the profitability of ETS in Malaysia? Hence, to achieve these objectives the paper is sub-divided into six sections. Following the introduction is the brief historical overview of ETS company in Malaysia and background about the service quality and customer satisfaction. The third section dwells on the literature review, research hypothesis and scope of the study. The fourth part explained the underpinning theory and theoretical framework of the study. The fifth part dealt with the research methodology, while the sixth segment involved the discussion of findings followed by conclusion and recommendations.

\section{Literature Review}

Customer satisfaction is an important aspect to improve service delivery to customer or user. Customer satisfaction is an overall evaluation for the consumption experience of the customer, every time during the consumption process can cause a satisfied or dissatisfied feeling. Hence, increasing quality on a service or product can satisfy the customers and numbers of loyalty customer will be increased as well (Hussain et al., 2015). Customer satisfaction is an uncertain element, one certain product may satisfy the customer and it may not satisfy another customer. Therefore, to increase the customer's satisfaction the maximum, the factors which may influence customer's satisfaction must be understood properly (Boo, 2017).

According to Nam, Baker, Ahmad \& Goo, (2018), Satisfaction is a summary of the psychological state that results when the excitement surrounding the disconfirmed expectations joins with previous consumer feelings about the experience of the consumer (pp. 24). Satisfaction depends on numerous factors and there is no shortage of literature on this theme. To generate the factors that lead to customer satisfaction we look at some research studies developed in this field (Agnihotri, Dingus, Hu \& Krush, 2016). However, according to El-Adly, (2019), terms of satisfaction can be defined as the experience of meeting an expected result. Satisfaction or dissatisfaction with a program or of physical equipment is influenced by previous expectations regarding the level of quality. Hapsari, Clemes \& Dean, (2016), argues that measurements of satisfaction do not match the actual behaviour of the client. In particular, he argues that a substantial number of respondents who describe themselves as satisfied or very satisfied are defectors and do not show loyalty to the brand that can be expected.

Service quality has been defined in many ways or concepts by scholars. For example, service quality was defined as overall customer impression of the relative inferiority or superiority of organization and its services. (Phan \& Nham, 2015). But, another researcher described service quality 
as a form of attitude representing a long-run overall evaluation. (Al-Azzam, 2015). Service quality on the basis of differences between expectations and performance on the quality dimension. (Pakurár, Haddad, Nagy, Popp \& Oláh, 2019).

Salkeld, (2015), said the quality of service is a relativistic intellectual mistake and between the rules and the exhibits about the benefits of the experience-based service. The quality of services is a concept that has attracted considerable interest and discussion in the research literature because of difficulties both in its definition and measurement without the consent (Salkeld, 2015). There are a number of different definitions of what is meant by quality of service. One that is commonly used defines the quality of service, such as the degree to which a service meets the needs and expectations of the customers (Kalaiarasan, Appannan \& Doraisamy, 2015; Aldaihani \& Ali, 2018). Quality of service can be defined as the difference between expectations of customer service and perceived service (Aldaihani \& Ali, 2018). Eid, (2015), stated that, if expectations are greater than performance, then perceived quality is less satisfactory and, accordingly, customer dissatisfaction occurs. If the expectations are higher performance, then perceived quality is less than satisfactory and therefore there is customer dissatisfaction. There is always an important issue because of why we would measure the quality of service.

The previous study conducted by Amin, (2016) showed that service quality is an important indicator of customer satisfaction. Attention to the service quality can make organization different from other organization and gain lasting competitive advantages (Hussain, Al Nasser \& Hussain, 2015). Afthanorhan, Awang, Rashid, Foziah \& Ghazali, (2019), satisfaction can be defined as the fulfilment of customer response, which includes an assessment based on the emotion of an answering service. Furthermore, Santouridis, Trivellas and Reklitis, (2009) investigated internet service quality and its impact on customer satisfaction in the banking context by adopting an instrument and it was also on the basis of SERVQUAL. They found that e-service quality are consists of six dimensions: assurance, quality of information, responsiveness, web assistance, empathy and reliability.

Prakoso et al., (2017), investigated into five dimensions such as reliability, responsiveness, assurance, empathy, and tangible that perceived service quality. In this regard, reliability is about the ability to delivery or performing the promised service accurately and dependably. Responsiveness is about the service provider willingly to help customers and provide prompt service. Furthermore, empathy is part involve caring, individualized attention the firm provides its customers. Assurance is defined as the employee knowledge and courtesy and the service provider's ability to inspire trust and confidence. Tangible is the appearance of physical facilities, equipment, personnel, and communication materials. However, Prakoso et al., (2017) found that there is influence by together between reliability, responsiveness, assurance, empathy, and tangible to customer satisfaction. The findings are also consistent with the study conducted by Farooq, Salam, Fayolle, Jaafar, \& Ayupp, (2018) who recommended airlines should focus on all dimensions of service quality to enhance the customer satisfaction. However, no similar previous studies have been conducted in the context of ETS, therefore, based on the previous studies on service quality that we prepared and investigate five hypotheses to test the customer satisfaction that include:

H1: There is relationship between reliability and customer satisfaction in ETS services.

$\mathrm{H} 2$ : There is relationship between responsiveness and customer satisfaction in ETS services.

H3:There is relationship between assurance and customer satisfaction in ETS services.

H4: There is relationship between empathy and customer satisfaction in ETS services.

H5: There is relationship between tangibility and customer satisfaction in ETS services.

\section{The Underpinning Theory - SERVQUAL Theory}

Service quality or SERVQUAL theory is a theory model developed Huang, Lin \& Fan, 2015). It highlights the main components of high quality service. The authors of the service quality theory, initially identified ten service quality elements, but in later works, fell in five multi-sized constant reliabilities, assurance, tangible, empathy and responsiveness. Companies using SERVQUAL to measure and manage the quality of the service by using a questionnaire that measures 
both the quality of customer service expectations in terms of these five dimensions as their perception of the service they receive. When customer expectations are greater than their perceptions of delivery, quality of service is considered low. In addition to being a measurement model, SERVQUAL is also a management model. The authors identified five SERVQUAL gaps that can cause customers to experience poor service quality. According to Huang, Lee \& Chen, (2019), service quality is a subjective evaluation that customers arrive by comparing the level of service we believe that an organization must provide the level of service they receive from being delivered. An extensive qualitative research conducted in the recent past suggests that deficiencies in service quality perceived by customers, for example, the gap between the expectations and perceptions, are caused by several organizational shortcomings. This research has included five independent variables and one dependent variable based the theoretical perspective of this study. These are presented in the research framework below:

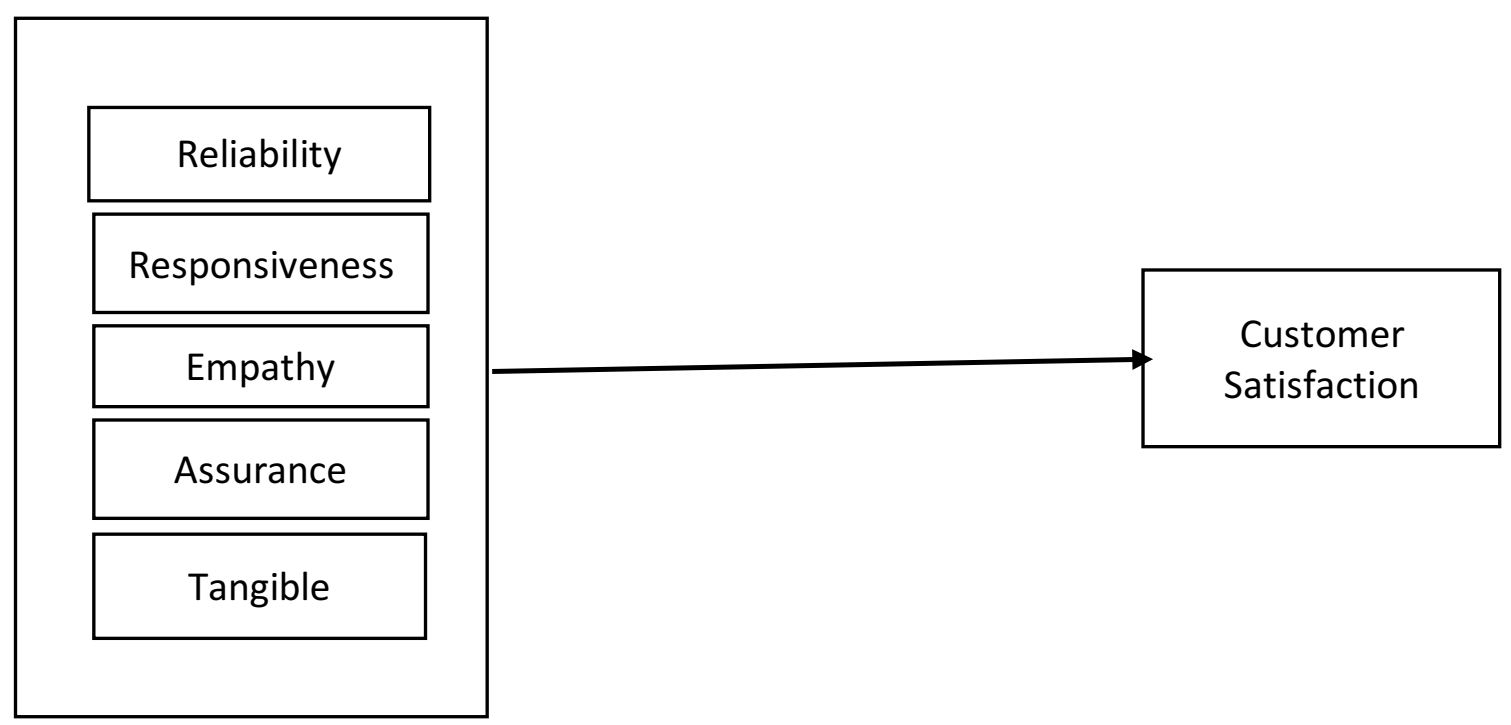

Figure 1. Research framework

\section{Research Method}

Descriptive research is a technique that describes the structures of the population or impression that is being studied. In this research, a questionnaire survey was utilized to examine the service quality that affect customer satisfaction towards Electric Train Service (ETS). The sample populations of the study cover student passengers as well as other passengers using the ETS at Keretapi Tanah Melayu Berhad (KTMB) Arau and Alor Setar train station located in the Northern region of Malaysia. The researcher uses quantitative research in descriptive form to explain the phenomenon under study. The selected respondents are based on simple random sampling technique. The respondents sample size was a total of 300 .

\section{Discussion of Findings}

Correlation between 2 variables

\begin{tabular}{lccccc}
\hline & Tangible & Responsiveness & Assurance & Reliability & Empathy \\
\hline $\begin{array}{l}\text { Customer } \\
\text { Satisfaction }\end{array}$ & $.446^{* *}$ & $.471^{* *}$ & $.466^{* *}$ & $.418^{* *}$ & $.467^{* * *}$ \\
\hline
\end{tabular}

**. Correlation is significant at the 0.01 levei (2-tailed). 
The result shows that all the variables are significant because significant level is $p<0.01$. So, all the hypothesis is supported, while the value of correlation for all variables is below 0.5 . It shows that the relationships between all independent variables and dependent variables has a negative relationship.

\begin{tabular}{llccccc}
\multicolumn{8}{c}{ ANOVA } \\
\hline \multicolumn{1}{l}{ Model } & Sum of Squares & df & Mean Square & F & Sig. \\
\hline \multirow{3}{*}{1} & Regression & 34.917 & 5 & 6.983 & 25.388 & $.000^{\text {b }}$ \\
& Residual & 78.394 & 285 & .275 & & \\
& Total & 113.311 & 290 & & & \\
\hline
\end{tabular}

a. Dependent Variable: Customer Satisfaction

b. Predictors: (Constant), Tangible, Responsiveness, Assurance, Reliability, Empathy

Regression analysis is conducted on the two variables. This is to determine if there is significant relationship with the variable. The results are shown in Table 2. From the regression result, the value of R2 was 0.308 meaning that the independent variable service quality with five dimensions (Tangible, responsiveness, Assurance, Reliability and Empathy) explains $27.9 \%$ variability on customer satisfaction. The results of the ANOVA shows the significant relationships between independents variables and dependents variables, where $F=25.388$ and $p=0.000(\alpha<0.05)$.

\begin{tabular}{ccccc}
\multicolumn{5}{c}{ Model summary } \\
\hline Model & R & R Square & Adjusted R Square & Std. Error of the Estimate \\
\hline 1 & $.555^{\mathrm{a}}$ & .308 & .296 & .52447 \\
\hline
\end{tabular}

a. Predictors: (Constant), Tangible, Responsiveness, Assurance, Reliability, Empathy

b. Dependent Variable: Customer satisfaction

The study determines whether the quality of a service-affecting customer satisfaction in the services provided by KTMB using underpinning theory based on SERVQUAL by Parasuraman. After the study it shows that only two variables are assurance and empathy that affect the relationship between service quality and customer satisfaction. It is consistent with the findings found in the results of study conducted by Santouridis, Trivellas and Reklitis, (2009). Meanwhile, three variables are responsiveness, reliability and tangibles not show the relationship between service quality and customer satisfaction. All these findings are partly consistent and inconsistent with the studies conducted by different authors (Prakoso et al., 2017; Farooq et al., 2018). In this regard, this study founds the ground for the future studies to enrich our findings in the different contexts in different industries and countries. The different results of the study from the studies where these variables were found have relationship could be due to the different types of contexts for example country, customers' attitude, feeling and so on towards ETS. However, it is significant that our study has achieved its main objectives to identify relationships between independent and dependent variables. In the course of this study, there are several limitations that are faced with an obstacle to the conduct of this study. Thus, several proposals have been made to solve the problem between independent variables were not significant with the dependent variable. Future research should extend the study to include larger samples to get wider coverage.

Conclusion

The objective of this research is to investigate the relationships between independents variables which is tangible, responsiveness, assurance, reliability, empathy and dependents variables which is customer satisfaction. The result shows that there are significant relationships between these two variables but has negative relationships. Based on service quality theory, it's stated that tangible, responsiveness, assurance, reliability and empathy will influence customer satisfaction. The results also show that all independents variables influence the dependents variables. This research objective has been achieved. The correlation analysis is beneficial when scholars are irritating to control if there is a connection between two variables. It is also significant to appreciate the change between a statistically important coefficient of correlation between the variables and the position to the sample. Studies reveal that the interactions between technical variables such as cross-tabulation and 
correlations. For future research, other variables could be applied in other to examine customer satisfaction.

\section{References}

Afthanorhan, A., Awang, Z., Rashid, N., Foziah, H., \& Ghazali, P. (2019). Assessing the effects of service quality on customer satisfaction. Management Science Letters, 9(1), 13-24.

Al-Azzam, A. F. M. (2015). The impact of service quality dimensions on customer satisfaction: A field study of Arab bank in Irbid city, Jordan. European Journal of Business and Management, 7(15), 45-53.

Aldaihani, F. M. F., \& Ali, N. A. (2018). Factors Affecting Customer Loyalty in the Restaurant Service Industry in Kuwait City, Kuwait. Journal of International Business and Management, 1(2), 1-14.

Aldaihani, F. M. F., \& Ali, N. A. B. (2018). Effect of Electronic Customer Relationship Management on Electronic Service Quality Provided by the Commercial Banks in Kuwait. International Journal of Academic Research in Accounting, Finance and Management Sciences, 8(2), 143-154.

Amin, M. (2016). Internet banking service quality and its implication on e-customer satisfaction and e-customer loyalty. International Journal of Bank Marketing, 34(3), 280-306.

Agnihotri, R., Dingus, R., Hu, M. Y., \& Krush, M. T. (2016). Social media: Influencing customer satisfaction in B2B sales. Industrial Marketing Management, 53, 172-180.

Boo, H. V. (2017). Service environment of restaurants: findings from the youth customers. Journal of ASIAN behavioural studies, 2(2), 67-77.

Chen, K. H., Wang, C. H., Huang, S. Z., \& Shen, G. C. (2016). Service innovation and new product performance: The influence of market-linking capabilities and market turbulence. International Journal of Production Economics, 172, 54-64.

Eid, R. (2015). Integrating Muslim customer perceived value, satisfaction, loyalty and retention in the tourism industry: An empirical study. International Journal of Tourism Research, 17(3), 249-260.

El-Adly, M. I. (2019). Modelling the relationship between hotel perceived value, customer satisfaction, and customer loyalty. Journal of Retailing and Consumer Services, 50, 322332.

Farooq, M. S., Salam, M., Fayolle, A., Jaafar, N., \& Ayupp, K. (2018). Impact of service quality on customer satisfaction in Malaysia airlines: A PLS-SEM approach. Journal of Air Transport Management, 67, 169-180.

Gabaix, X., \& Laibson, D. (2018). Shrouded attributes, consumer myopia and information suppression in competitive markets. In Handbook of Behavioral Industrial Organization. Edward Elgar Publishing.

Hapsari, R., Clemes, M., \& Dean, D. (2016). The mediating role of perceived value on the relationship between service quality and customer satisfaction: Evidence from Indonesian airline passengers. Procedia Economics and Finance, 35, 388-395.

Hassan, R. S., Nawaz, A., Lashari, M. N., \& Zafar, F. (2015). Effect of customer relationship management on customer satisfaction. Procedia economics and finance, 23, 563-567.

Hussain, R., Al Nasser, A., \& Hussain, Y. K. (2015). Service quality and customer satisfaction of a UAE-based airline: An empirical investigation. Journal of Air Transport Management, 42, 167-175.

Huang, E. Y., Lin, S. W., \& Fan, Y. C. (2015). MS-QUAL: Mobile service quality measurement. Electronic Commerce Research and Applications, 14(2), 126-142.

Huang, P. L., Lee, B. C., \& Chen, C. C. (2019). The influence of service quality on customer satisfaction and loyalty in B2B technology service industry. Total Quality Management \& Business Excellence, 30(13-14), 1449-1465. 
Kalaiarasan, K., Appannan, S., \& Doraisamy, B. (2015). A Study on Service Quality on Customer Satisfaction in Low Cost Airline Industries. International Journal of Science, Environment and Technology, 4(4), 1126-1138.

Lee, M., Kang, M., \& Kang, J. (2019). Cultural influences on B2B service quality-satisfactionloyalty. The Service Industries Journal, 39(3-4), 229-249.

Loo, C. L., Chua, S. F., Foong, H. Z., Loke, K., \& Pang, E. C. (2016). Service Quality on Behavioural Purchase Intentions in the Public Land Transportations Service in Kuala Lumpur, Malaysia (Doctoral dissertation, UTAR).

Nam, K., Baker, J., Ahmad, N., \& Goo, J. (2018). Dissatisfaction, disconfirmation, and distrust: An empirical examination of value co-destruction through negative electronic word-ofmouth (eWOM). Information Systems Frontiers, 1-18.

Pan, F. C. (2015). Practical application of importance-performance analysis in determining critical job satisfaction factors of a tourist hotel. Tourism Management, 46, 84-91.

Pakurár, M., Haddad, H., Nagy, J., Popp, J., \& Oláh, J. (2019). The service quality dimensions that affect customer satisfaction in the Jordanian banking sector. Sustainability, 11(4), 1113.

Phan, C., \& Nham, P. (2015). Impact of service quality on customer satisfaction of automated teller machine service: case study of a private commercial joint stock bank in Vietnam. Business: Theory and Practice, 16, 280.

Prakoso, et al., (2017). Reliability, Responsiveness, Assurance, Empathy, And Tangible: Still Can Satisfy The Customer. International Journal of Business and Management Invention, 6(3), 68-75.

Quester, P. G., Romaniuk, S., \& Wilkinson, J. W. (2015). A test of four service quality measurement scales: the case of the Australian advertising industry. In Proceedings of the 1995 World Marketing Congress (pp. 384-391). Springer, Cham.

Rashid, I. M. A., Rani, M. J. A., Yusuf, B. N. M., \& Shaari, M. S. (2015). The Impact of Service Quality and Customer Satisfaction on Customer's Loyalty: Evidence from Fast Food Restaurant of Malaysia. International Journal of Information, Business and Management, 7(4), 201-258.

Santouridis, I. , Trivellas, P. and Reklitis, P. (2009) Internet service quality and customer satisfaction: examining internet banking in Greece, Total Quality Management, 20(2),. 223-239. Salkeld, J. S. (2015). The Role expectations and perceptions of service quality in the evaluation of corporate education programmes (Doctoral dissertation, Bournemouth University).

Santouridis, I. , Trivellas, P. and Reklitis, P. (2009) Internet service quality and customer satisfaction: examining internet banking in Greece, Total Quality Management, 20(2), pp. 223-239.

Vogus, T. J., \& McClelland, L. E. (2016). When the customer is the patient: Lessons from healthcare research on patient satisfaction and service quality ratings. Human Resource Management Review, 26(1), 37-49. 